Setiawati, Rois dan 'Aini / 2017

\title{
PENGARUH KECUKUPAN MODAL, RISIKO PEMBIAYAAN, EFISIENI OPERASIONAL DAN LIKUIDITAS TERHADAP PROFITABILITAS (Studi Pada Bank Syariah dan Bank Konvensional di Indonesia)
}

\author{
Erma Setiawati ${ }^{1}$ \\ * Akuntansi, Fakultas Ekonomi dan Bisnis, Universitas Muhammadiyah Surakarta \\ *Erma.Setyowati@ums.ac.id ${ }^{l}$ \\ Dimas Ilham Nur Rois ${ }^{2}$ \\ *Magister Akuntansi, Pasca Sarjana, Universitas Muhammadiyah Surakarta \\ *dimasilham94@gmai.com² \\ Indah Nur 'Aini" \\ *Akuntansi, Fakultas Ekonomi dan Bisnis, Universitas Muhammadiyah Surakarta \\ *indahnurin27@gmail.com ${ }^{3}$
}

\begin{abstract}
The competition between conventional and Islamic banks is quite strict, this becomes a common trend because the banks want to attract and maintain the relation with their costumer, each bank must try and work hard to show their optimal financial performances.This research aims to find out the effect of capital adequacy, financing risk, operational efficiency and liquidity on the profitability of Islamic banks and Conventional banks, as well as to analyze the differences effect of capital adequacy, financing risk, operational efficiency and liquidity on profitability in Islamic banks and conventional banks in Indonesia. Population in this research are all Islamic bank and a conventional bank that listed in Indonesian bank (Bank Indonesia) on 2011-2015. This research using purposive sampling technique, with the samples involving three Islamic bank and four conventional banks in Indonesia. The data is analyzed by multiple regression analysis and descriptive analysis. The result of this research shows that the capital adequacy and operational efficiency has a significant effect on the profitability of Islamic banks. The financing risk and liquidity have no significant effect on the profitability of Islamic banks. While the capital adequacy, operational efficiency, and liquidity have a significant effect on their profitability conventional banks, and the financing risk is not affected to conventional banks profitability. The result of this research also showed that there's a difference in the effect of capital adequacy, financing risk, operational efficiency and liquidity on profitability between Islamic banks and Conventional Bank.
\end{abstract}

Keywords: capital adequacy, financing risk, operational efficiency, liquidity and profitability

\section{Pendahuluan}

Pada tahun 1997 kondisi perekonomian di Indonesia mengalami keterpurukan yang mana dampaknya juga dapat dirasakan oleh salah satunya yaitu sektor perbankan. Namun, seiring berjalannya waktu kini bank telah bangkit, tumbuh dan mulai menunjukkan adanya perkembangan yang sangat pesat.

Selama ini bank dikenal sebagai lembaga yang memiliki peran penting dalam perekonomian suatu negara, fungsi salah satu bank yaitu menghimpun dana dari masyarakat dan kemudian dislaurkan kembali dana tersebut kepada masyarakat dengan tujuan membantu mensejahterakan kehidupan masyarakat maupun negara. Dalam menjalankan kegiatan usahanya bank dapat dikategorikan menjadi dua, yaitu bank konvensional dan bank berbasis syariah. Perbedaan mendasar antara kedua bank tersebut terletak pada pendapatan yang diperoleh melalui kegiatan penggunaan maupun peminjaman dana yang dilakukan oleh nasabah, dimana bank konvensional menetapkan sistem bunga sedangkan bank berbasis syariah tidak membebankan bunga atas kegiatan tersebut. Selain itu, bank syariah dalam memperoleh keuntungan maupun dalam hal menghadapi risiko menganut prinsip kebersamaan dan keadlian.

Persaingan antara bank konvensional dengan bank berbasis syariah bisa dikatakan cukup ketat, hal 
ini dikarenakan untuk menarik minat maupun mempertahankan hubungan dengan nasabahnya, masing-masing dari kedua bank tersebut harus saling berusaha dan bekerja keras untuk menunjukkan kinerja keuangan yang optimal.

Kinerja keuangan dapat digunakan untuk menentukan kondisi kesehatan suatu bank. Kinerja keuangan bank merupakan bagian dari kinerja bank secara keseluruhan, hal ini merupakan gambaran prestasi yang dicapai bank dalam operasionalnya, baik menyangkut aspek keuangan, pemasaran, penghimpunan dan penyaluran dana, teknologi, maupun sumber daya manusia (Putri, Fadah dan Endhiarto, 2015). Sementara, tingkat profitabilitas biasa digunakan untuk menunjukkan kinerja suatu bank. Angka profitabilitas yang tinggi menunjukkan kinerja bank yang baik begitu juga sebaliknya. Untuk menilai kinerja keuangan perbankan umumnya digunakan lima aspek penilaian yaitu CAMEL (Capital, Assets, Management, Earning, Liquidity). Aspek capital meliputi CAR, aspek assets meliputi NPL, aspek earning meliputi NIM dan BOPO, aspek liquidity meliputi LDR dan GWM (Ponco, 2008) dalam Eng (2013).

Pada penelitian ini kecukupan modal, risiko pembiayaan, efisieni operasional dan likuiditas digunakan sebagai variabel independen yang mempengaruhi profitailitas pada bank syariah maupun konvensional.

Tujuan dilakukannya penelitian ini, yaitu (1) untuk menganalisis pengaruh kecukupan modal, risiko pembiayaan, efisiensi operasional dan likuiditas terhadap profitabilitas pada bank umum syariah. (2) untuk menganalisis pengaruh kecukupan modal, risiko pembiayaan, efisiensi operasional dan likuiditas terhadap profitabilitas pada bank umum konvensional. (3) untuk menganalisis perbedaan pengaruh kecukupan modal, risiko pembiayaan, efisiensi operasional dan likuiditas terhadap profitabilitas pada bank umum syariah dan bank konvensional di Indonesia.

\section{Kajian Pustaka dan Pengembangan Hipotesis}

\section{Teori Agensi (Agency Theory)}

Teori agensi (agency theory) menjelaskan adanya hubungan kontraktual antara dua atau lebih pihak, dimana salah satu pihak disebut prinsipal (principal) yang menyewa pihak lain disebut agen (agent) dalam melakukan beberapa jasa atas nama pemilik yang meliputi pendelegasian wewenang (Lukitasari dan Kartika, 2014). Dalam teori ini principal digambarkan sebagai pemilik atau pemegang saham, sedangkan agent digambarkan sebagai orang yang diberi kuasa oleh principal yaitu manajemen yang bertanggung jawab untuk mengelola perusahaan. Dalam hubungan pemisahan kepemilikan dalam sebuah organisasi cenderung menimbulkan konflik keagenan antara principal dan agent. Maka dari itu, teori ini muncul untuk membantu mengatasi konflik agensi yang dapat terjadi dalam hubungan keagenan.

\section{Teori Stewardship}

Teori yang digunakan pada penelitian ini yaitu teori stewardship. Teori stewardship adalah teori yang dicetuskan oleh Donaldson dan Davis, teori ini menggambarkan situasi dimana para manajer tidaklah termotivasi oleh tujuan-tujuan individu tetapi lebih ditujukan pada sasaran hasil utama mereka untuk kepentingan organisasi, sehingga teori ini mempunyai dasar psikologi dan sosiologi yang telah dirancang dimana para eksekutif sebagai steward termotivasi untuk bertindak sesuai keinginan prinsipal, selain itu perilaku steward tidak akan meninggalkan organisasinya sebab steward berusaha mencapai sasaran organisasinya. Teori ini didesain bagi para peneliti untuk menguji situasi dimana para eksekutif dalam perusahaan sebagai pelayan dapat termotivasi untuk bertindak dengan cara terbaik pada principalnya (Zamrana, 2010 dalam Riyadi dan Yulianto, 2014).

Stewardship Theory dapat dipahami dalam produk pembiayaan lembaga perbankan. Bank syariah sebagai prinsipal yang mempercayakan nasabah sebagai steward untuk mengelola dana yang idealnya mampu mengakomodasi semua kepentingan bersama antara principal dan steward yang mendasarkan pada pelayan yang memiliki perilaku dimana dia dapat dibentuk agar selalu dapat diajak bekerjasama dalam organisasi, memiliki perilaku kolektif atau berkelompok dengan utilitas tinggi dari pada individualnya dan selalu bersedia untuk melayani.

\section{Bank}

Bank secara sederhana dapat diartikan sebagai Lembaga Keuangan yang kegiatan utamanya adalah menghimpun dana dari masyarakat dan 
menyalurkannya kembali dana tersebut ke masyarakt serta memberikan jasa bank lainnya (Kasmir, 2012:12). Dari pengertian tersebut dapat diartikan bahwa bank merupakan lembaga intermediasi dalam bidang keuangan dengan tujuan utamanya yaitu memperoleh laba yang berasal dari pendapatan bunga yang diterima bank melalui transaksi penyaluran kredit kepada masyarakat.

\section{Perbankan Syariah}

Dalam pasal 1 Undang undang No. 21 Tahun 2008 tentang perbankan syariah disebutkan bahwa bank adalah badan usaha yang menghimpun dana masyarakat dalam bentuk simpanan dan menyalurkannya kepada masyarakat dalam bentuk kredit dan atau bentuk-bentuk lainnya dalam rangka meningkatkan taraf hidup rakyat banyak. Sedangkan menurut UU No 7 Tahun 1992 tentang perbankan sebagaimana telah diubah dengan UU No 10 tahun 1998, pengertian bank adalah badan usaha yang menghimpun dana dari masyarakat dalam bentuk simpanan dan menyalurkannya kepada masyarakat dalam bentuk kredit dan atau bentuk-bentuk lainnya dalam rangka meningkatkan taraf hidup rakyat banyak.

Perbankan syariah dalam peristilahan internasional dikenal sebagai Islamic Banking atau juga disebut dengan interest-free banking. Peristilahan tersebut tidak dapat dilepaskan dari asal mula sistem perbankan syariah. Bank islam atau selanjutnya disebut dengan Bank Syariah adalah bank yang beroperasi dengan tidak mengandalkan pada bunga. Untuk menghindari pengoperasian bank dengan sistem bunga, islam memperkenalkan prinsip-prinsip muamalah islam (Muhammad, 2014:3). Prinsip syariah adalah hukum islam dalam kegiatan perbankan berdasarkan fatwa yang dikeluarkan oleh lembaga yang memiliki kewenangan dalam penetapan fatwa di bidang syariah. Bank Umum Syariah (BUS) adalah bank syariah yang kegiatannya memberikan jasa dalam lalu lintas pembayaran.

\section{Profitabilitas}

Profitabilitas merupakan kemampuan yang dimiliki oleh suatu perusahaan dalam menghasilkan laba. Sebutan lain untuk profitabilitas adalah rasio rentabilitas. Rasio ini digunakan untuk mengukur tingkat efisiensi usaha dan prifitabilitas yang dicapai oleh bank yang bersangkutan (Kasmir, 2012:327). Dalam menghitung profitabilitas digunakan sebuah alat pengukuran yang disebut ROA (Return On Assets). Menurut Hanafi dan Halim (2016:157) ROA mengukur kemampuan perusahaan menghasilkan laba dengan menggunakan total aset (kekayaan) yang dipunyai perusahaan setelah disesuaikan dengan biayabiaya untuk mendanai aset tersebut.

Profitabilitas merupakan tujuan utama dari suatu perusahaan, di samping itu profitabilitas juga dapat digunakan untuk mengukur kinerja suatu perusahaan. Menurut Prasetyo (2015) semakin tinggi tingkat profitabilitas dan terus-menerus memperoleh profitabilitas, maka semakin baik kinerja perbankan atau perusahaan dan kelangsungan hidup perbankan atau perusahaan tersebut akan terjamin.

\section{Kecukupan modal}

Kecukupan modal adalah suatu regulasi perbankan yang menetapkan suatu kerangka kerja mengenai bagaimana bank dan lembaga penyimpanan harus menangani permodalan mereka (Kartika, 2014). Kecukupan Modal menggambarkan kemampuan bank dalam mempertahankan modal yang mencukupi untuk menutup risiko kerugian yang mungkin timbul dari penanaman dana dalam aset produktif yang mengandung risiko, serta untuk pembiayaan dalam asset tetap dan investasi. Modal yang memadai dapat meningkatkan kepercayaan masyarakat, karena mengindikasikan bahwa bank dapat menanpung kemungkinan risiko kerugian yang akan dialami oleh bank akibat kegiatan operasional bank. Dengan begitu, kecukupan modal akan berdampak pada meningkatnya keuntungan atau profitabilitas yang diperoleh bank melalui bunga pinjaman kredit. CAR merupakan indikator yang sering digunakan untuk mengukur tingkat kecukupan modal bank. CAR dapat diperoleh melalui perhitungan rasio atau perbandingan antara modal sendiri dengan ATMR.

Hasil penelitian Akhtar, Ali dan Sadaqat (2011) pmenunjukkan bahwa semakin besar Capital Adequacy Ratio (CAR) maka profitabilitas bank syariah yang diperoleh bank akan semakin besar pula. Karena semakin besar Capital Adequacy Ratio (CAR) maka semakin tinggi permodalan bank dalam menjaga kemungkinan timbulnya risiko kerugian pada kegiatan usahanya, sehingga kinerja bank juga akan meningkat. Kinerja bank yang meningkat berarti memberikan kontribusi lebih pada profitabilitas.

Hasil penelitian sebelumnya yang dilakukan oleh Margaretha dan Zai (2013), Anggreni dan 
Suardhika (2014) serta Saputra dan Budiasih (2016) yang menunjukkan bahwa CAR berpengaruh positif dan signifikan terhadap profitabilitas bank konvensional. Semakin besarnya CAR maka dapat meningkatkan profitabilitas (ROA), karena bank dapat membiayai aktiva yang mengandung risiko. Berdasarkan pemaparan sebelumnya, maka hipotesis yang dapat diajukan adalah sebagai berkut:

\section{$\mathrm{H}_{1 \mathrm{a}}$ : Kecukupan Modal berpengaruh terhadap Profitabilitas Bank Syariah}

\section{$H_{1 b}$ : Kecukupan Modal berpengaruh terhadap} Profitabilitas Bank Konvensional

\section{Risiko Pembiayaan}

Risiko Pembiayaan digunakan untuk mengukur tingkat permasalahan pembiayaan yang dihadapi oleh bank syariah. Risiko Pembiayaan dapat diukur dengan rasio Non Performing Financing (NPF). Berangkat dari rasio Non Performing Loan (NPL), Non Performing Financing (NPF) merupakan versi NPL bagi bank syariah. Tingkat bagi hasil (profit distribution) yang akan diterima nasabah sangat bergantung pada jumlah dana yang disalurkan dan seberapa baik kualitas pembiayaan yang diberikan bank. Hal ini akan mempengaruhi perolehan laba dari penggunaan dana nasabah, hal ini bisa diindikasi melalui tingkat Risiko Pembiayaan. Non Performing Financing (NPF) mencerminkan risiko pembiayaan, jadi semakin tinggi rasio ini menunjukkan kualitas pembiayaan bank syariah semakin buruk. Pengelolaan pembiayaan sangat diperlukan oleh bank, mengingat fungsi pembiayaan sebagai penyumbang pendapatan terbesar bank syariah.

Hasil penelitian terdahulu Muwaddah (2015) dan Abdurrahman (2014) menjelaskan bahwa Non Performing Financing (NPF) berpengaruh signifikan positif terhadap profitabilitas bank syariah. Beberapa penelitian yang pernah dilakukan sebelumnya seperti Eng (2013), Anggreni dan Suardhika (2014) serta Prasetyo (2015) menyatakan hasil penelitiannya bahwa NPL memiliki pengaruh negatif dan signifikan terhadap profitabilitas bank konvensional. Dengan perubahan penurunan pada NPL atau kredit bermasalah dapat mengakibatkan profitabilitas yang semakin meningkat. Berdasarkan pemaparan sebelumnya, maka hipotesis yang dapat diajukan adalah sebagai berkut:

\section{$\mathrm{H}_{2 \mathrm{a}}$ : Risiko Pembiayaan berpengaruh terhadap Profitabilitas Bank Syariah}

\section{$\mathrm{H}_{2 \mathrm{~b}}$ : Risiko Pembiayaan berpengaruh terhadap Profitabilitas Bank Konvensional}

\section{Efisiensi Operasional}

BOPO merupakan rasio antara biaya operasional terhadap pendapatan operasional. Biaya operasional merupakan biaya yang dikeluarkan oleh bank dalam rangka menjalankan aktivitas usaha utamanya seperti biaya bunga, biaya pemasaran, biaya tenaga kerja, dan biaya operasional lainnya. Rasio BOPO menunjukan efisiensi bank dalam menjalankan usaha pokoknya terutama kredit, dimana bunga kredit menjadi pendapatan terbesar perbankan.

Hasil penelitian Wibowo (2013) menunjukkan BOPO berpengaruh signifikan terhadap profitabilitas bank syariah. Sesuai dengan teori yang mendasarinya bahwa semakin kecil BOPO menunjukkan semakin efisien bank dalam menjalankan kegiatan usahanya. Sehingga apabila semakin kecil BOPO, laba periode berikutnya akan semakin besar. Hal ini dikarenakan BOPO yang rendah menunjukkan biaya operasi yang lebih kecil dari pendapatan operasinya. Sedangkan hasil penelitian sebelumnya pada bank konvensional yaitu Prasanjaya dan Ramantha (2013), Lukitasari dan Kartika (2014) serta Saputra dan Budiasih (2016) menyatakan bahwa rasio BOPO sebagai variabel bebas dalam penelitiannya menunjukkan pengaruh negatif dan signifikan terhadap profitabilitas bank konvensional. Berdasarkan pemaparan sebelumnya, maka hipotesis yang dapat diajukan adalah sebagai berkut:

\section{$\mathrm{H}_{3 \mathrm{a}}$ : Efisiensi Operasionalberpengaruh terhadap Profitabilitas Bank Syariah \\ $\mathrm{H}_{3 \mathrm{~b}}$ : Efisiensi Operasionalberpengaruh terhadap Profitabilitas Bank Konvensional}

\section{Likuiditas}

Likuiditas adalah cerminan dari fungsi intermediasi bank, yaitu dalam menyalurkan dana pihak ketiga ke pembiayaan. Likuiditas menunjukkan kesediaan bank dalam memberikan pinjaman kredit kepada masyarakat. Ketika perusahaan mampu memberikan pinjaman yang cukup besar kepada masayarakat, hal ini bisa menjadi andalan bagi bank untuk menarik perhatian dan sekaligus dapat menigkatkan image bank dimata masyarakat. Dengan begitu, bank akan mendapat kepercayaan dari masyarakat, sehingga masyarakat akan berbondong untuk melakukan investasi dan pinjaman kepada bank 
yang mana pendapatan yang diperoleh tersebut dapat meningkatkan laba atau profitabilitas bank. Likuiditas dapat diukur dengan financing to deposit ratio (FDR). Istilah loan to deposit ratio (LDR) lebih banyak digunakan dalam bank konvensional, sedangkan

$$
\mathrm{CAR}=\frac{\text { Modal Bank }}{\text { Aktiva Tertimbang Menurut Risiko }} \times 100 \%
$$

financing to deposit ratio (FDR) pada bank syariah, karena dalam perbankan syariah tidak dikenal istilah kredit (loan) namun pembiayaan (Antonio, 2001:170).

Hasil penelitian sebelumnya yaitu Slamet Riyadi (2014) menjelaskan bahwa Financing Deposits Rasio (FDR) berpengaruh signifikan positif terhadap profitabilitas bank syariah. Sedangkan hasil penelitian sebelumnya pada bank konvensional yang menunjukkan bahwa LDR berpengaruh signifikan terhadap profitabilitas bank konvensional adalah penelitian yang dilakukan oleh Eng (2013), Margaretha dan Zai (2013) serta Lukitasari dan Kartika. Berdasarkan pemaparan sebelumnya, maka hipotesis yang dapat diajukan adalah sebagai berkut:

\section{$\mathrm{H}_{4 \mathrm{a}}$ : Likuiditas berpengaruh terhadap Profitabilitas Bank Syariah \\ $\mathbf{H}_{4 \mathrm{~b}}$ : Likuiditas berpengaruh terhadap Profitabilitas Bank Konvensional}

\section{Metode Penelitian}

Penelitian ini merupakan jenis penelitian kuantitatif dengan melakukan pengujian hipotesis. Populasi dalam penelitian ini adalah seluruh perbankan persero dan perbankan syariah yang terdaftar di Bank Indonesia periode 2011 sampai dengan 2015. Teknik pengambil sampel menggunakan teknik purposive sampling, yaitu dilakukan dengan cara mengambil sampel dari populasi berdasarkan kriteria tertentu.

Data yang digunakan adalah data sekunder berupa laporan keuangan triwulan perbankan yang dijadikan sampel selama periode 2011 sampai dengan 2015. Laporan keuangan tersebut dapat diakses melalui situs Bank Indonesia yaitu www.bi.go.id maupun situs masing-masing bank yang dijadikan sampel dalam penelitian ini.

\section{Variabel Dependen Profitabilitas}

Profitabilitas merupakan kemampuan perusahaan dalam menghasilkan laba yang dapat digunakan sebagai pengukur kinerja perusahaan.
Profitabilitas diukur dengan menggunakan pengukuran ROA (Return On Asset), yaitu dengan cara membandingkan laba sebelum pajak dibagi dengan total aktiva. Rasio ini dapat dirumuskan sebagai berikut:

$$
\text { ROA }=\frac{\text { Laba Sebelum Pajak }}{\text { Total Aktiva }} \times 100 \%
$$

\section{Variabel Independen}

\section{Kecukupan Modal}

Kecukupan modal merupakan regulasi suatu perusahaan perbankan yang disepakati oleh perusahaan dalam penanganan permodalan yang mereka miliki. CAR merupakan rasio pemodalan yang menunjukkan kemampuan bank dalam menyediakan dana untuk keperluan pengembangan usaha dan menampung risiko kerugian dana yang diakibatkan oleh kegiatan operasi bank (Ali, 2004:132). Variabel ini diukur menggunakan skala rasio, yaitu berdasarkan persentase perbandingan Modal dengan Aktiva Tertimbang Menurut Risiko. Rasio CAR dapat dirumuskan sebagai berikut:

\section{Risiko Kredit}

Risiko kredit adalah suatu peristiwa yang mungkin dialami oleh bank akibat kreditur yang tidak dapat bertanggung jawab untuk membayar hutang beserta bunganya pada waktu jatuh tempo yang sudah disepakati pada saat transaksi dilakukan. NPL sering digunakan dalam metode pengukuran risiko kredit. NPL adalah rasio perbandingan kredit bermasalah dengan total kredit. Rumus NPL dapat ditulis sebagai berikut:

$$
\text { NPL }=\frac{\text { Kredit Bermasalah }}{\text { Total Kredit }} \times 100 \%
$$

\section{Efisiensi Operasional}

Efisiensi operasional merupakan perbandingan antara rencana penganggaran yang akan dikeluarkan dengan pendapatan yang akan diterima suatu perusahaan maupun perbankan. Indikator yang sering digukana untuk mengukur efisiensi operasional adalah rasio BOPO. Rumus rasio BOPO dapat ditulis sebagai berikut:

$$
\text { BOPO }=\frac{\text { Biaya Operasional }}{\text { Pendapatan Operasional }} \times 100 \%
$$




\section{Likuiditas}

Likuiditas dapat diartikan sebagai kemampuan perusahaan dalam memenuhi kewajibannya yang harus segera dibayar (Tawan, 2010:246). Loan to Deposit Ratio merupakan rasio untuk mengukur komposisi jumlah kredit yang diberikan dibandingkan dengan jumlah dana masyarakat dan modal sendiri yang digunakan (Kasmir, 2012:319). Rasio LDR dapat dirumuskan seagai berikut:

$$
\text { LDR }=\frac{\text { Kredit }}{\text { Dana Pihak Ketiga }} \times 100 \%
$$

\section{Metode Analisis Data}

Penelitian ini menggunakan metode analisis Regresi Liner Berganda. Analisis regresi berganda dapat digunakan untuk mengetahui bagaimana variabel independen dapat mempengaruhi secara akurat

\begin{tabular}{|l|c|c|c|}
\hline \multicolumn{4}{|l|}{ Bank Konvensional } \\
\hline Konstanta & 7,796 & 8,691 &, 000 \\
\hline CAR &, 142 & 4,773 &, 000 \\
\hline NPL &,- 082 &,- 971 &, 335 \\
\hline BOPO &,- 129 & $-14,521$ &, 000 \\
\hline LDR &, 025 & 4,009 &, 000 \\
\hline Adj.R ${ }^{2}$ & 0,918 & & \\
\hline F & 201,665 & & \\
\hline F Sig. & 0,000 & & \\
\hline$p$-value & 0,05 & & \\
\hline
\end{tabular}

variabel dependen. Berikut adalah model persamaan umum regresi linier berganda dalam penelitian ini:

$$
\begin{aligned}
& \text { ROA }=\alpha+\beta_{1} \text { CAR }+\beta_{2} \mathrm{NPL}+\beta_{3} \text { BOPO }+\beta_{1} \mathrm{LDR}+ \\
& \text { e (1) } \\
& \text { ROA }=\alpha+\beta_{1} \text { CAR }+\beta_{2} \text { NPL }+\beta_{3} \text { BOPO }+\beta_{1} \text { LDR }+ \\
& e \quad(2)
\end{aligned}
$$

Keterangan:

$$
\begin{array}{ll}
\text { ROA } & =\text { Profitabilitas } \\
\alpha & =\text { konstanta } \\
\beta_{1}-\beta_{4} & =\text { koefisien regresi } \\
\text { CAR } & =\text { Kecukupan Modal } \\
\text { NPL } & =\text { Risiko Pembiayaan } \\
\text { BOPO } & =\text { Efisiensi Operasional }
\end{array}
$$

$$
\begin{aligned}
\mathrm{LDR} & =\text { Likuiditas } \\
e & =\text { error } \\
(1) \quad & =\text { persamaan pada Bank Syariah } \\
(2) & =\text { persamaan pada Bank Konvensional }
\end{aligned}
$$

\section{Hasil dan Pembahasan}

Pemilihan sempel berdasarkan kriteria yang telah ditentukan sebelumnya maka diperoleh 49 sample bank syariah dan 73 sampel bank konvensional.

\section{Hasil Analisis Regresi}

Hasil pengujian data menunjukkan bahwa data lulus uji asumsi klasik. Selanjutnya hasil analisis regresi berganda sebagai berikut:

Tabel 1. 1

Hasil Uji Regresi Berganda

\begin{tabular}{|l|c|c|c|}
\hline Variabel & Koef. & T & Sig \\
\hline \multicolumn{3}{|l|}{ Bank Syariah } \\
\hline Konstanta & 9,159 & 5,067 & 0,000 \\
\hline CAR & $-0,104$ & $-2,244$ & 0,030 \\
\hline NPL & 0,057 & 0,247 & 0,806 \\
\hline BOPO & $-0,072$ & $-4,462$ & 0,000 \\
\hline LDR & 0,001 & 0,098 & 0,930 \\
\hline Adj.R ${ }^{2}$ & 0,499 & & \\
\hline F & 12,962 & & \\
\hline F Sig. & 0,000 & & \\
\hline$p$-value & 0,05 & & \\
\hline Sub: Dan
\end{tabular}

Sumber: Data sekunder yang diolah, 2017.

Berdasarkan tabel diatas, maka diperoleh persamaan regresi sebagai berikut:

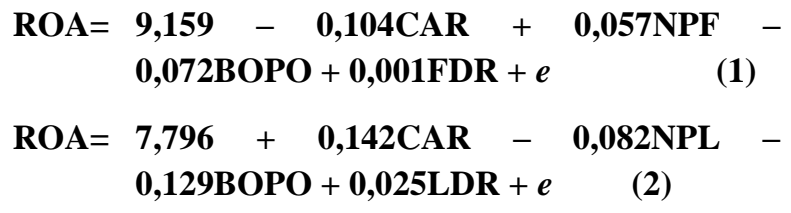

Hasil uji koefisien determinan (Adj. $\mathrm{R}^{2}$ ) pada bank syariah menunjukkan angka sebesar 0,499 yang berarti bahwa variabel profitabilitas dapat dijelaskan oleh variabel kecukupan modal, risiko pembiayaan, efisiensi operasional, dan likuiditas sebesar 49,9\%, sedangkan sisanya yaitu $51,9 \%$ dijelaskan oleh 
variabel lain yang tidak diteliti dalam penelitian ini. Sedangkan, hasil pada bank syariah menunjukkan angka sebesar 0,918 yang berarti bahwa variabel profitabilitas dapat dijelaskan oleh variabel kecukupan modal, risiko pembiayaan, efisiensi operasional, dan likuiditas sebesar $91,8 \%$ dan sisanya $8,2 \%$ dijelaskan oleh variabel lain di luar model.

Hasil uji $F$ dapat diketahui tingkat signifikansinya pada bank syariah maupun bank konvensional memiliki angka, yaitu sebesar 0,000. Hal ini menunjukkan bahwa secara simultan variabel kecukupan modal, risiko pembiayaan, efisiensi operasional dan likuiditas berpengaruh terhadap profitabilitas baik pada bank syariah maupun bank konvensional.

Berdasarkan tabel 1.1 secara parsial pada bank syariah yang mempengaruhi profitabilitas bank adalah variabel kecukupan modal dan efisiensi operasional, sedangkan pada bank konvensional variabel yang mempengaruhi profitabilitas yaitu kecukupan modal, efisiensi operasional dan likuiditas.

\section{Pembahasan}

\section{Pada Bank Syariah}

\section{a. Pengaruh Kecukupan Modal terhadap} Profitabilitas Bank Syariah

Berdasarkan hasil penelitian variabel Kecukupan Modal (CAR) diperoleh nilai thitung sebesar -2,244 dengan tingkat signifikansi yaitu sebesar $0,000<0,05$. Hasil ini menunjukkan bahwa $\mathrm{H}_{1 \mathrm{a}}$ diterima. Dengan demikian berarti bahwa Kecukupan Modal memiliki pengaruh yang signifikan terhadap Profitabilitas. Namun, hasil pengujian mengindikasi jika kecukupan modal meningkat maka profitabilitas akan menurun. Hasil penelitian ini berbeda dengan teori yang telah dijelaskan sebelumnya bahwa semakin tinggi CAR maka bank akan mampu membiayai kegiatan operasionalnya dan memberikan kontribusi besar terhadap tingkat profitabilitasnya. Perbedaan ini dapat disebabkan karena modal dengan jumlah besar yang dimiliki perbankan apabila tidak dikelola secara efektif dan ditempatkan pada investasi-investasi yang menghasilkan keuntungan tidak akan mampu memberikan kontribusi bagi tingkat profitabilitas perbankan bersangkutan.

\section{b. Risiko Pembiayaan berpengaruh terhadap Profitabilitas Bank Syariah}

Berdasarkan hasil penelitian variabel Risiko Pembiayaan diperoleh nilai $t_{\text {hitung }}$ sebesar 0,247 dengan tingkat signifikansi lebih besar dari $0,05(0,806>0,05)$. Hal ini berarti bahwa $\mathrm{H}_{2 \mathrm{a}}$ ditolak dan menunjukan bahwa Risiko Pembiayaan tidak berpengaruh terhadap Profitabilitas.

Hal ini membuktikan semakin besar Risiko Pembiayaan menurunkan tingkat Profitabilitas. Dengan demikian semakin tinggi Risiko Pembiayaan memberikan penurunan Profitabilitas. Hal ini dikarenakan pengaruh yang signifikan dari Risiko Pembiayaan terhadap Profitabilitas adalah berkaitan dengan kemacetan pembiayaan yang diberikan oleh sebuah bank. Disisi lain adanya Risiko Pembiayaan yang tinggi akan dapat mengganggu perputaran modal kerja dari bank. Apabila bank memiliki jumlah pembiayaan macet yang tinggi, maka bank akan terlebih dahulu berusaha mengevaluasi kinerja mereka yang dengan sementara menghentikan penyaluran pembiayaan hingga Risiko Pembiayaan berkurang. Dari data yang diperoleh, Risiko Pembiayaan yang diukur dengan NPF bank syariah relatif kecil atau sedikit yang macet.

\section{c. Efisiensi Operasional berpengaruh terhadap Profitabilitas Bank Syariah}

Berdasarkan hasil penelitian variabel Efisiensi Operasional diperoleh nilai $\mathrm{t}_{\text {hitung }}$ sebesar -4,462 dengan tingkat signifikansi lebih kecil dari $0,05(0,000<0,05)$. Hal ini berarti $\mathrm{H}_{3 a}$ diterima, menunjukan bahwa Efisiensi Operasional berpengaruh signifikan terhadap Profitabilitas. Dari hasil penelitian ini menunjukkan semakin kecil atau rendahnya tingkat Efisiensi Operasional menunjukkan beban operasional yang lebih kecil dari pendapatan operasional bank, dan membuktikan semakin efisien beban operasional yang dikeluarkan bank. Efisiensi operasional bank berdampak pada pendapatan laba atau profitabilitas yang semakin besar. Efisiensi Operasional akan memberikan kepercayaan lebih kepada masyarakat atau nasabah untuk menempatkan investasi sehingga tingkat profitabilitas meningkat. Dengan demikian semakin rendah Efisiensi Operasional perbankan syariah bisa menjadi tolak ukur 
keberhasilan bank syariah dalam melakukan aktivitas bagi hasilnya. Hal ini menunjukkan bahwa semakin besar pembiayaan bank maka laba yang diperoleh bank semakin kecil.

\section{d. Likuiditas berpengaruh terhadap Profitabilitas Bank Syariah}

Berdasarkan hasil penelitian pada variabel Likuiditas diperoleh nilai $t_{\text {hitung }}$ sebesar 0,098 dengan signifikansi lebih besar dari 0,05 $(0,930>0,05)$. Hasil ini menunjukkan bahwa $\mathrm{H}_{4 \mathrm{a}}$ ditolak. Dengan demikian dapat disimpulkan bahwa semakin tinggi Likuiditas perbankan syariah tidak bisa menjadi tolak ukur keberhasilan bank dalam aktivitas bagi hasilnya. Dengan kata lain kenaikan Likuiditas bukan merupakan faktor yang menyebabkan kenaikan Profitabilitas. Likuditas tidak berpengaruh terhadap profitabilitas karena dinilai bank kurang maksimal dalam menggunakan dana pihak ketiga dalam pembiayaan. Bank diniliai lebih banyak menggunakan aktiva untuk pembiayaan nasabahnya.

\section{Pada Bank Konvensional}

\section{a. Pengaruh Kecukupan Modal terhadap Profitabilitas Bank Konvensional}

Berdasarkan hasil uji $\mathrm{t}$ variabel Kecukupan Modal (CAR) diperoleh nilai $t_{\text {hitung }}$ sebesar 4,773 dengan tingkat signifikansi yaitu sebesar $0,000<0,05$. Hasil ini menunjukkan bahwa $\mathrm{H}_{1 b}$ diterima. Dengan demikian berarti bahwa Kecukupan Modal memiliki pengaruh yang signifikan terhadap Profitabilitas.

Hasil penelitian ini mendukung penelitian Margaretha dan Zai (2013), Anggreni dan Suardhika (2014), Saputra dan Budiasih (2016) yang menyatakan bahwa kecukupan modal berpengaruh positif dan signifikan terhadap profitabilitas. Dalam penelitian ini dapat diketahui bahwa kecukupan modal suatu bank menjadi faktor penting dalam kegiatan operasional bank yang dapat mempengaruhi profitabilitas. Menurut Margaretha dan Zai (2013) CAR merupakan indikator terhadap kemampuan bank untuk menutupi penurunan aktivanya sebagai akibat dari kerugian-kerugian bank yang disebabkan oleh aktiva yang berisiko dengan kecukupan modal yang dimilikinya.
Selain itu, bank memiliki fungsi untuk menghimpun dana dari masyarakat dan kemudian dikembalikan lagi dalam bentuk pinjaman. Dengan demikian, apabila bank memiliki modal yang cukup dalam pemberian pinjaman kepada msayarakat, maka bank juga akan memperoleh keuntungan dari hasil kegiatan operasionalnya tersebut yang mana keuntungan yang diperoleh dapat meningkatkan laba atau profitabilitas bank itu sendiri. Berdasarkan penjelasan tersebut maka dapat dikatakan bahwa semakin tinggi CAR maka semakin tinggi pula profitabilitas (ROA).

\section{b. Pengaruh Risiko Kredit terhdap Profitabilitas Bank Konvensional}

Berdasarkan hasil uji t, Risiko Kredit (NPL) diperoleh nilai $t_{\text {hitung }}$ sebesar-0,971 dengan tingkat signifikansi yaitu $0,355>0,05$. Hasil ini menunjukkan bahwa $\mathrm{H}_{2 \mathrm{~b}}$ ditolak. Dengan demikian dapat disimpulkan Risiko Kredit tidak berpengaruh terhadap Profitabilitas.

Hasil penelitian ini mendukung penelitian yang dilakukan oleh Lukitasari dan Kartika (2014) yang menunjukkan bahwa NPL tidak berpengaruh terhadap ROA. Dalam penelitian ini risiko kredit yang diukur dengan menggunakan rasio NPL, jika dilihat dari hasil analisis deskriptif dari keempat bank yang dijadikan sampel NPL memiliki rata-rata $1,2742 \%$ yang dinilai masih cukup rendah karena berada di bawah batas maksimal yang ditetapkan Bank Indonesia yaitu sebesar 5\%. Secara logika NPL yang rendah dapat meningkatkan ROA, sebaliknya jika NPL tinggi maka dapat mengakibatkan penurunan ROA. Namun logika tersebut bisa terpatahkan oleh hasil pengujian dalam penelitian ini yang menyebutkan bahwa tingkat rasio NPL tidak berpengaruh terhadap ROA. Perusahaan tidak bisa jika terus berfokus pada penurunan NPL, karena perusahaan perbankan yang memiliki risiko kredit macet (NPL) tinggi dimungkinkan masih dapat ditutupi dengan cara meningkatkan kecukupan modal (CAR) dan likuiditasnya (LDR) sehingga profitabilitas (ROA) yang dihasilkan bank masih tetap bisa meningkat. Dengan demikian dapat disimpulkan bahwa tingkat rasio NPL dalam penelitian ini tidak memiliki pengaruh terhadap perubahan profitabilitas perusahaan perbankan. 


\section{c. Pengaruh Efisiensi Operasional terhadap Profitabitas Bank Konvensional}

Berdasarkan hasil uji t, Efisiensi Operasional yang diukur melalui rasio BOPO diperoleh nilai $t_{\text {hitung }}$ sebesar $-14,521$ dengan tingkat signifikansi yaitu $0,000<0,05$. Hasil ini menunjukkan bahwa $\mathrm{H}_{0}$ ditolak dan diterimanya $\mathrm{H}_{3 \mathrm{~b}}$. Dengan demikian dapat disimpulkan bahwa Efisiensi Operasional berpengaruh signifikan terhadap Profitabilitas.

Hasil dari penelitian ini sejalan dengan penelitian yang dilakukan oleh Prasanjaya dan Ramantha (2013), Margaretha dan Zai (2013), Lukitasari dan Kartika (2014), Prasetyo (2015), Saputra dan Budiasih (2016) yang menyebutkan bahwa efisiensi operasional yang diukur dengan BOPO berpengaruh dan signifikan secara statistik pada profitabilitas bank. Dalam penelitian ini menggambarkan adanya hubungan negatif antara efisiensi operasional dengan profitabilitas, hal tersebut menjelaskan bahwa biaya operasional yang dikeluarkan memiliki jumlah yang sedikit, dengan begitu pendapatan yang diperoleh dari hasil kegiatan operasional bank akan bertambah sehingga dapat berdampak pada peningkatan profitabilitas bank. Jadi, semakin rendahnya rasio BOPO maka dengan begitu dapat meningkatkan profitabilitas bank. Hal ini berhubungan dengan efisiensi operasional bank, rasio BOPO yang tinggi menunjukkan bahwa bank belum mampu memanfaatkan dan menggunakan sumber daya yang dimiliki secara baik dan benar atau dapat dikatakan belum mampu menjalankan kegiatan usahanya secara efisien, sebaliknya rasio BOPO yang rendah mengindikasikan bahwa bank tersebut telah mampu menjalankan usahanya secara efisien.

\section{d. Pengaruh Likuiditas terhadap Profitabilitas Bank Konvensional}

Berdasarkan hasil uji t variabel Likuiditas yang diukur dengan LDR diperoleh nilai $t_{\text {hitung }}$ sebesar 4,009 dengan tingkat signifikansi yaitu $0,000<0,05$. Hasil ini menunjukkan bahwa $\mathrm{H}_{4 \mathrm{~b}}$ diterima. Dengan demikian berarti Likuiditas memiliki pengaruh terhadap Profitabilitas.

Hasil penelitian ini konsisten dengan penelitian Prasanjaya dan Ramantha (2013), Eng (2013), Lukitasari dan Kartika (2014) yang menyatakan likuiditas berpengaruh signifikan terhadap profitabilitas. Dalam penelitian ini menunjukkan bahwa likuiditas yang menggambarkan kemampuan suatu bank dalam menyalurkan kredit kepada masyarakat dapat mempengaruhi profitabilitas. Perusahaan perbankan dengan LDR yang tinggi mengindikasikan bahwa perusahaan tersebut memiliki kinerja penyaluran kredit yang baik dan efektif, serta memiliki jumlah risiko pembiayaan macet yang kecil, sehingga dapat berakibat pada peningkatan profitabilitas bagi perusahaan perbankan. Dengan demikian, dapat disimpulkan bahwa tingginya LDR dapat meningkatkan ROA.

\section{Pada Bank Syariah dan Bank Knvensional}

a. Perbedaan pengaruh Kecukupan Modal terhadap Profitabilitas antara Bank Syariah dan Bank Konvensional

Dalam penelitian ini hasil olah data baik pada bank syariah maupun bank konvensional, keduanya terdapat pengaruh kecukupan modal terhadap profitabilitas, tetapi pada bank syariah berpengaruh negatif sedangkan pada bank konvensional berpengaruh positif. Hal ini disebabkan karena bank syariah belum lama berdiri dibandingkan bank konvensional sehingga ada kemungkinan modal besar dalam bank syariah dalam penempatan investasinya kurang efektif dibandingkan bank konvensional.

\section{b. Perbedaan pengaruh Risiko Pembiayaan terhadap Profitabilitas antara Bank Syariah dan Bank Konvensional}

Dalam penelitian ini melalui olah data diperoleh hasil bahwa baik pada bank syariah maupun konvensional risiko pembiayaan tidak memiliki pengaruh terhadap profitabilitas. Hal ini bisa saja terjadi, meskipun dengan adanya nilai NPL yang tinggi perusahaan masih bisa berupaya untuk mempertahankan profitabilitasnya dengan cara meningkatkan nilai CAR. Jadi, meskipun perusahaan tersebut mengalami permasalahan risiko pembiayaan, namun hal tersebut masih bisa ditutupi dengan kepemilikan modal yang besar sehingga profitabilitas (ROA) yang dihasilkan bank tidak berubah atau bahkan masih tetap bisa meningkat. 
c. Perbedaan pengaruh Efisiensi Operasional terhadap Profitabilitas antara Bank Syariah dengan Bank Konvensional

Dalam hasil penelitian ini data yang talah diolah memberikan hasil bahwa variabel efisiensi operasional memiliki pengaruh terhadap profitabilitas pada bank syariah maupun bank konvensional. Nilai rasio BOPO pada masingmasing bank menunjukkan angka negatif, yang berarti semakin rendahnya rasio BOPO maka akan meningkatkan nilai ROA pada bank.

Hal ini menunjukkan bahwa bank mampu memanfaatkan dan menggunakan sumber dayanya dengan sesuai dan benar. Sehingga operasional bank dapat berjalan secara efisien dan dengan begitu profitabilitas bank akan turut meningkat sejalan dengan efisiensi operasional bank.

\section{d. Perbedaan pengaruh Likuiditas terhadap Profitabilitas antara Bank Syariah dengan Bank Konvensional}

Hasil penelitian yang diperoleh melalui pengolahan data menunjukkan bahwa likuiditas pada bank syariah tidak berpengaruh terhadap profitabilitas, sedangkan likuiditas pada bank konvensional berpengaruh terhadap profitabilitas. Hal ini bisa saja disebabkan karena kurang optimalnya penggunaan likuiditas, bank syariah lebih sering menggunakan aktivanya dibandingkan dana pihak ketiga untuk kegiatan pembiayaan. Sehingga tingkat likuiditasnya tidak begitu mempengaruhi profitabilitas. Berbeda dengan bank konvensional yang memiliki kinerja penyaluran kredit lebih optimal dan efektif, serta memiliki jumlah risiko pembiayaan macet yang kecil, sehingga dapat memberikan dampak pada peningkatan profitabilitas bagi bank konvensional.

\section{Simpulan}

Berdasarkan hasil pengujian sebelumnya, maka dapat disimpulkan:

1) Kecukupan modal berpengaruh terhadap profitabilitas Bank Syariah.

2) Risiko pembiayaan tidak berpengaruh terhadap profitabilitas Bank Syariah.

3) Efisiensi operasional berpengaruh terhadap profitabilitas Bank Syariah.
4) Likuiditas tidak berpengaruh terhadap profitabilitas Bank Syariah.

5) Kecukupan modal berpengaruh terhadap profitabilitas Bank Konvensional.

6) Risiko pembiayaan tidak berpengaruh terhadap profitabilitas Bank Konvensional.

7) Efisiensi operasional berpengaruh terhadap profitabilitas Bank Konvensional.

8) Likuiditas berpengaruh terhadap profitabilitas Bank Konvensional.

Terdapat perbedaan pengaruh kecukupan modal, risiko pembiayaan, efisiensi operasional dan likuiditas terhadap profitabilitas antara Bank Syariah dengan Bank Konvensional.

\section{Referensi}

[1] Abdulilah, Mona. 2009. "Profitability Determination of Commercial Banks In Malaysia After The 1997 Financial Crisis". Jurnal Thesis : Universitas Utara Malaysia.

[2] Abdurrahaman.2014. Analisis Pengaruh Jumlah Kredit Mikro Yang Diberikan Dan Non Performing Loan Terhadap Profitabilitas Pada PT. Bank Syariah Mandiri KCP Buleleng Periode Tahun 2012-2013. Dalam Jurnal Akuntansi. Singaraja : Universitas Pendidikan Ganesha.

[3] Akhtar, Ali, Sodaqat. 2011. Factors Influencing the Profitability of Islamic Banks of Pakistan.

[4] Ali, Masyhud. 2004. Asset Liability Management: Menyiasati Risiko Pasar dan Risiko Operasional dalam Perbankan. Jakarta: PT. Elex Media Komputindo.

[5] Anggreni, Made Ria dan I Made Sadha Suardhika. 2014. Pengaruh Dana Pihak Ketiga, Kecukupan Modal, Risiko Kredit dan Suku Bunga Kredit Pada Profitabilitas. ISSN: 23028556. E-Jurnal Akuntansi Universitas Udayana.

[6] Antonio, Muhammad Syafi'I. 2001. Bank Syariah dari Teori Ke Praktek. Jakarta : Gema Insani Pers-Tazkia.

[7] Aristya, Diah. 2010. "Analisis Pengaruh Ukuran Perusahaan, Kecukupan Modal, Kualitas Aktiva Produktif, , dan Likuiditas Terhadap Kinerja Keuangan Bank Syariah”. Semarang: UNDIP.

[8] Bank Indonesia. Laporan Keuangan tahun 2011-2015. http://www.bi.go.id 
[9] Bank Negara Indonesia. Laporan Keuangan tahun 2011-2015. http://www.bni.go.id

[10] Bank Mandiri. Laporan Keuangan tahun 20112015. http://www.mandiri.go.id

[11] Bank Rakyat Indonesia. Laporan Keuangan tahun 2011-2015. http://www.bri.go.id

[12] Bank Tabungan Negara. Laporan Keuangan tahun 2011-2015. http://www.btn.go.id

[13] Dendawijaya, Lukman. 2005. Manajemen Perbankan, Edisi Kedua, Cetakan Pertama. Bogor: Ghalia Indonesia.

[14] Dendawijaya, Lukman. 2009. Manajemen Perbankan. Jakarta: Ghalia Indonesia.

[15] Dewi, Dhika Rahma. 2011. Faktor-faktor yang mempengaruhi Profitabilitas Bank Syariah D $i$ Indonesia.Semarang: UNDIP

[16] Eng, Sau Tan. 2013. Pengaruh NIM, BOPO, $L D R, N P L \&$ \& CAR Terhadap ROA Bank Internasional dan Bank Nasional Go Public Periode 2007-2011. ISSN: 2338-123X. Jurnal Dinamika Manajemen. Volume 1. Nomor 3.

[17] Firdaus, H Rachmat \& Maya Ariyanti. 2009. Manajemen Perkreditan Bank Umum. Bandung: Alfabetta.

[18] Ghozali, Imam. 2011. Aplikasi Analisis Multivariate dengan Program IBM SPSS 19, Edisi 5. Semarang: Badan Penerbit Universitas Diponegoro.

[19] Ghozali, Imam. 2012. Aplikasi Aanalisis Multivariate dengan Program IBM SPSS 20. Semarang: Badan Penerbit Universitas Diponegoro.

[20] Hanafi, M. Mamduh dan Abdul Halim. 2016. Analisis Laporan Keuangan. Yogyakarta: UPP STIM YKPN.

[21] Heri Sudarsono. 2008. Bank dan Lembaga Keuangan Syariah. Yogyakarta: Ekonosia.

[22] Ikatan Akuntan Indonesia. 2007. Kerangka Dasar Penyusunan dan Penyajian Laporan Keuangan Bank Syariah. Jakarta: Salemba Empat.

[23] Jogiyanto. 2008. Meotodologi Penelitian Sitem Informasi: Pedoman dan Contoh Melakukan Penelitian di Bidang Sistem Teknologi Penelitian. Yogyakarta: C.V ANDI OFFSET.

[24] Karim, Adiwarman A. 2006. Bank Islam: Analisis Fiqh dan Keuangan. Jakarta: PT. Raja Grafindo Persada.
[25] Kasmir. 2012. Manajemen Perbankan. Jakarta: PT Raja Grafindo Persada.

[26] Laporan Triwulanan. www.bi.go.id www.megasyariah.co.id www.bnisyariah.co.id www.syariahmandiri.co.id

[27] Lukitasari, Yunia Putri dan Andi Kartika. 2014. Faktor-faktor yang Mempengaruhi Kinerja Keuangan pada Sektor Perbankan yang terdaftar di Bursa Efek Indonesia. ISSN: 19794878. Dinamika Akuntansi, Keuangan dan Perbankan. Volume 3. Nomor 2.

[28] Margaretha, Farah dan Marsheilly Pingkan Zai. 2013. Faktor-faktor yang Mempengaruhi Kinerja Keuangan Perbankan Indonesia. ISSN: 1410-9875. Jurnal Bisnis dan Akuntansi. Volume 15. Nomor 2.

[29] Taswan. 2010. Manajemen Perbankan Konsep, Teknik, dan Aplikasi. Yogyakarta: UPP STIM YKPN.

[30] Muhammad. 2002. Bank Syariah Analisis Kekuatan, Kelemahan, Peluang, dan Ancaman. Yogyakarta: Ekonosia.

[31] Muhammad. 2005. Manajemen Bank Syariah. Yogyakarta: UPP AMP YPKN.

[32] Muhamad. 2014. Manajemen Dana Bank Syariah. Jakarta: PT Raja Grafindo Persada.

[33] Mulianti. 2010. Analisis Faktor-Faktor yang Mempengaruhi Kebijakan Hutang dan Pengaruhnya terhadap Nilai Perusahaan. Tesis. Semarang: Program Pasca Sarjana Universitas Diponegoro.

[34] Muwadah. 2015. Faktor faktor yang mempengaruhi profitabilitas bank syariah.

[35] Nisviati dan Wibowo Andoko. 2013. Studi Komparasi Kinerja Keuangan Bank Syariah Mandiri (Perbankan Syariah) dan Bank Mandiri (Perbankan Konvensional). ISSN: 2302-240X. Volume 3. Nomor 2. www.cahayasurya.ac.id/jurnal

[36] Nurhayati, Sri dan Wasilah. 2011. Akuntansi Syariah di Indonesia. Jakarta: Salemba Empat.

[37] Nurkhosidah, Siti. 2010. "Analisis Pengaruh variabel Non Performing Financing, Penyisihan Penghapusan Aktiva Produktif, Financing to Deposit Ratio, Biaya Operasional per Pendapatan Operasional, Terhadap Profitabilitas Pada Bank Syariah Mandiri, Yogyakarta: UIN Sunan Kalijaga. 
[38] Peraturan Bank Indonesia No. 10/15/PBI/2008 Pasal 2 ayat 1.

[39] Puspitasari, Diana. 2009. Analisis Pengaruh CAR, NPL, PDN, NIM, BOPO, LDR, dan Suku Bunga Sbi Terhadap ROA. Tesis. Magister Manajemen, Universitas Diponegoro Semarang.

[40] Prasanjaya, A. A. Yogi dan I Wayan Ramantha. 2013. Analisis Pengaruh Rasio CAR, BOPO, LDR, dan Ukuran Perusahaan terhadap Profitabilitas Bank yang Terdaftar di BEI. ISSN: 2302-8556. E-Jurnal Akuntansi Universitas Udayana.

[41] Prasetyo, Wawan. 2015. Analisis Faktor-faktor yang Mempengaruhi Profitabilitas Perbankan. ISSN: 2086-1575. JESP. Vol 07. No 1.

[42] Purnamasari, Gusti Ayu Yuliani_dan Dodik Ariyanto. 2016. Analisis Perbandingan Kinerja Keuangan Bank Konvensional dan Bank Syariah Periode 2010-2014. ISSN: 2302-8556. E-Jurnal Akuntansi Vol.15.1. Universitas Udayana.

[43] Putri, dkk. 2015. Analisis Perbandingan Kinerja Keuangan Bank Konvensional dan Bank Syariah. JEAM. Vol XIV April 2015.

[44] Rahman, Rochmanika. 2012. Pengaruh Pembiayaan Jual Beli, Pembiayaan Bagi Hasil, dan Rasio Non Performing Financing terhadap Profitabilitas Bank Umum Syariah di Indonesia. Fakultas Ekonomi dan Bisnis Universitas Brawijaya.

[45] Rivai, Veithzal dan Arviyan Arifin. 2010 Islamic Banking : Sebuah Teori, Konsep, dan Aplikasi. Jakarta: Bumi Aksara.

[46] Riyadi, Slamet. 2014. Pengaruh Pembiayaan Jual Beli, Pembiayaan Bagi Hasil, FDR, dan NPF Terhadap Profitabilitas Bank Umum Syariah Di Indonesia. Dalam Jurnal Akuntansi. Semarang: Universitas Negeri Semarang.

[47] Sahara, Ayu Yanita. 2013. Analisis Pengaruh CAL, NPL, BOPO, NIM, dan LDR Terhadap ROA (Studi kasus Pada Perushaan Perbankan Yang Terdaftar di Bursa Efek Indonesia Periode 2004-2007). Semarang : Universitas Diponegoro.

[48] Santoso, Singgih. 2000. Buku Latihan SPSS Statistik Parametrik. Jakarta: PT Elex Media Komputindo.
[49] Saputra, I Made Hendra Edy dan I Gusti Ayu Nyoman Budiasih. 2016. Pengaruh Kecukupan Modal, Risiko Kredit, Biaya Operasional Pendapatan Operasional pada Profitabilitas Bank. ISSN: 2302-8559. E-Jurnal Akuntansi Universitas Udayana.

[50] Sari, D.W. 2013. "Pengaruh Pembiayaan Jual Beli, Bagi Hasil, Financing to Deposit Ratio dan Non Performing Financing Terhadap Profitabilitas Bank Indonesia". Skripsi. Semarang: Jurusan Manajemen UNDIP.

[51] Sekaran, Uma. 2010. Research Methods for Business A Skill Building Approach. Jakarta: Salemba Empat.

[52] Sofyan, Sofriza. Pengaruh Struktur Pasar Terhadap Kinerja Perbankan Di Indonesia. Media Riset Bisnis \& Manajemen.Vol.2, No.3, Desember 2012.

[53] Solikah, dkk. 2017. Analisis Perbandingan Kinerja Keuangna Bank Umum Syariah dengan Bank Umum Konvensional di Indonesia (Studi Empiris pada Perusahaan Perbankan di Bursa Efek Indonesia). Warta Ekonomi. Volume 7. Nomor 17.

[54] Sugiyono, P. D. 2014. Cara Mudah Menyusun Skripsi, Tesis, dan Disertasi. Bandung: ALFABETA, cv.

[55] Surat Edaran Bank Indonesia No.26/5/BPPP Tanggal 29 Mei 1993.

[56] Suryani. 2011. AnalisisPengaruh Financing to Deposit Ratio Terhadap Profitabilitas Perbankan Syariah. Dalam Jurnal Akuntansi. Aceh: STAIN Malikussaleh.

[57] Wibowo, Edhi dkk. 2013. Analisis Pengaruh Suku Bunga, Inflasi, CAR, BOPO, NPF Terhadap Profitabilitas Bank Syariah. Dalam Jurnal Akuntansi. Semarang: Universitas Diponegoro. 